\title{
ОБЩАЯ ХАРАКТЕРИСТИКА БОЛЕЗНЕЙ И ИХ ВОЗБУДИТЕЛЕЙ НА РАСТЕНИЯХ КУКУРУЗЫ, КУЛЬТИВИРУЕМОЙ В УСЛОВИЯХ АЗЕРБАЙДЖАНА
}

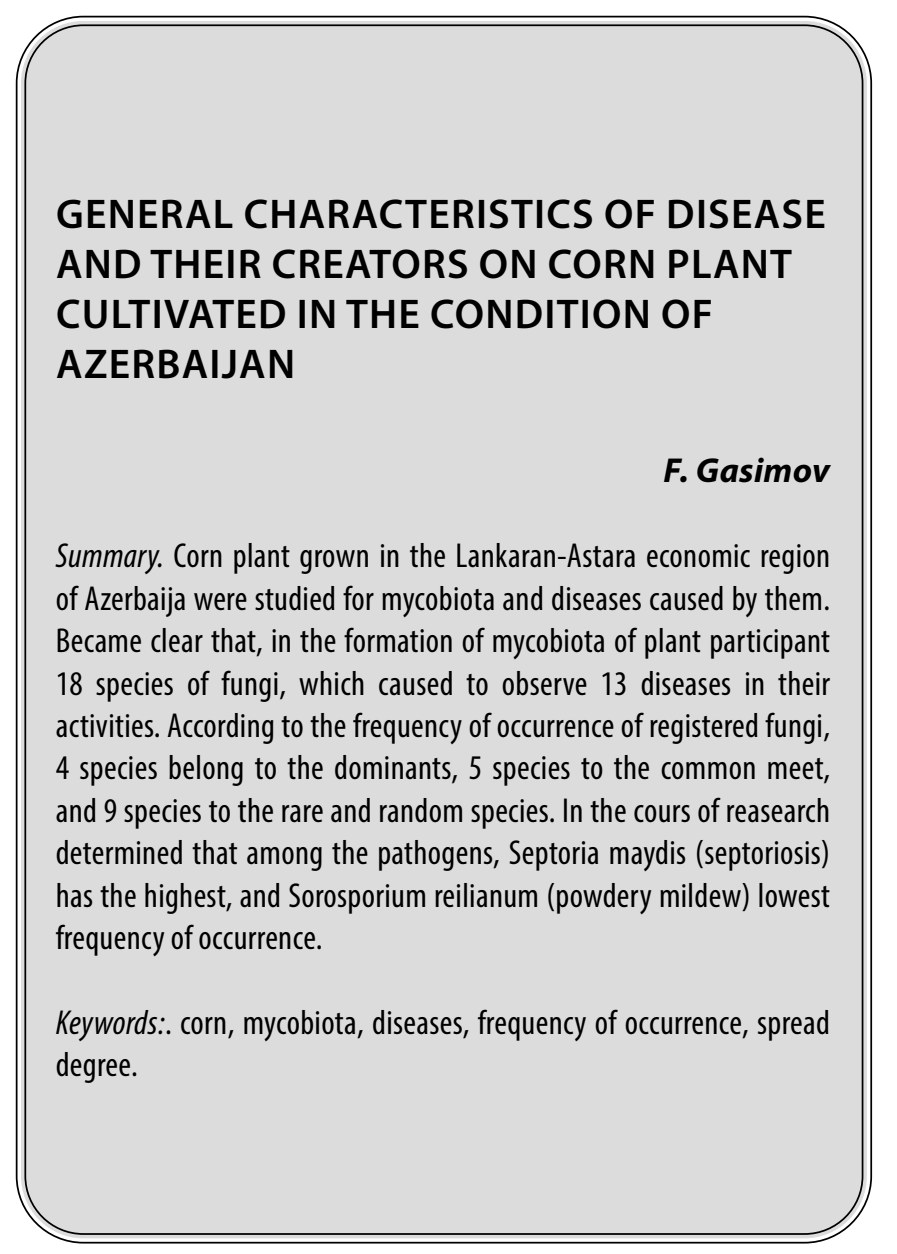

B последнее время человечество сталкивается с разнохарактерными событиями, которые требуют пересмотра существующей инфраструктуры, производственных площадей и создания их в соответствии с принципами устойчивого развития. На фоне решения этих вопросов сельское хозяйство и связанные с ним отрасли экономики развивающихся стран [10], в том числе Азербайджана [11], играют сегодня роль источника средств, необходимых для поддержания жизнедеятельности людей.

В Азербайджане, как и в других странах, занимающихся аграрной отраслью, при выращивании сельскохозяйственных культур не всегда достигаются желаемые результаты урожайности [1]. Из числа причин данного явления следует отметить неиспользование
Гасумов Джейхун Фаиг оглы

Докторант, НИИ Земледелия Министерства Сельского Хозяйства Азербайджанской Республики, 2. Баку

ceyhun_qasimov_75@mail.ru

Аннотация. Исследована микобиота и вызываемые ею заболевания кукурузы, выращиваемой в Ленкоранско-Астаринском экономическом районе Азербайджана. Выявлено, что в формировании микобиоты растения участвуют 18 видов грибов, в результате деятельности которых проявляется 13 заболеваний. По частоте встречаемости зарегистрированных грибов 4 вида относятся к доминирующим видам, 5 видов - к часто встречающимся и 9 видов - к редким и случайным видам. (реди возбудителей заболеваний наиболее часто встречающимся видом является гриб Septoria maydis (септориоз), а наименее - Sorosporium reilianum (пыльная головня кукурузы).

Ключевые слова: кукуруза, микобиота, болезнь, частота встречаемости, степень распространенности. научно обоснованных технологий возделывания, недостаточный учет динамики абиотических и биотических факторов окружающей среды, недостаточная урожайность и устойчивость к болезням сортов, используемых при выращивании сельскохозяйственных культур и т.п. Среди этих причин особое значение имеют заболевания и вред, причиняемый рядом микро- и макроорганизмов, которые играют важную роль в потере получаемого или предполагаемого урожая [15]. В связи с этим можно составить первоначальное представление о серьезности проблемы, отметив лишь один факт, а именно то, что ежегодно только из-за грибковых заболеваний [9] урожайность сельскохозяйственных культур в мире снижается не менее чем на 10\%. Поэтому учет этого вопроса, то есть проведение исследований, направленных на решение проблем, приводя- 
Таблица 1. Видовой состав грибов, встречающихся на кукурузе

\begin{tabular}{|l|l|}
\hline Принадлежность к таксону & Виды \\
\hline Mycota & $\begin{array}{l}\text { Alternaria alternate, Botrytiscinerea, Colletotrichum graminicola, Diplodiazeae, Fusarium } \\
\text { graminearum, F.oxysporum, F.verticillioides, Gibberellazeae, Helminthosporium maydis, H.turcicum, } \\
\text { Nigrosporaoryzae, Puccinia sorghi, Sclerotinialibertiana, Scl.sclerotiorum, Septoria maydis, } \\
\text { Sorosporiumreilianum, Ustilagozeae }\end{array}$ \\
\hline Chromista & Pythium debaryanum \\
\hline
\end{tabular}

щих к снижению урожайности сельскохозяйственных культур, выращиваемых для получения продуктов различного назначения, является одной из задач, которая остается актуальной в условиях роста численности мирового населения и спроса на эти продукты.

Среди сельскохозяйственных культур особое значение имеет кукуруза [3-4]. Так, это растение выращивается в мире практически повсеместно и по своему назначению служит как для кормовых (2/3 кукурузы, производимой на земле), так и для пищевых (20\%) и технических целей (15\%). Кроме того, кукуруза также используется в народной медицине как мочегонное средство, то есть растение также имеет лечебное значение и издавна используется в народной медицине. Даже при выращивании такого важного широкоспектрного растения по указанным выше причинам не может быть получен ожидаемый урожай, т.е. в этом случае происходит также потеря урожая. Исследования по их устранению ведутся давно, и в этой области получены успешные результаты. Однако, как уже отмечалось, этот вопрос, в частности, предотвращение потерь урожая из-за болезней, еще не нашёл своего эффективного решения, и количество потерь урожая в настоящее время оценивается в миллионы тонн во всем мире.

Поэтому целью данной работы является выявление болезней и их возбудителей, наблюдаемых при возделывании кукурузы в Ленкоранско-Астаринском экономическом районе.

\section{Материалы и метолы}

Исследование проводилось в Ленкоранско-Астаринском экономическом районе, который охватывает южный регион Азербайджанской Республики. Образцы были взяты из вегетативных и генеративных органов кукурузы (в основном сорта Загатала-420), выращиваемых в этом районе, в которых предполагается наличие грибов. Выделение грибов в чистую культуру из взятых образцов, определение частоты встречаемости и т.д. проводилось в соответствии с известными методами и подходами [5-6], а также использованными в нашей предыдущей работе [14].
Для выделения грибов в чистую культуру использовали агар Сабуро и агаризованное солодовой сусло, а также агаризованную среду Чапека [6], а для идентификации чистых культур использовали определители $[2,7-8,12-13]$, основанные на культурально- морфологических характеристиках грибов.

\section{Результаты и их обсужкения}

Результаты исследования видового состава микобиоты кукурузы, выращиваемой в Ленкоранско-Астаринском экономическом районе Азербайджана, показали, что растение кукурузы является одной из сред обитания грибов, в том числе их патогенных видов, и включает виды, принадлежащие как к истинным грибам, так и к грибоподобным организмам (таблица 1). Как видно, 94,4\% из 18 зарегистрированных видов грибов являются истинными грибами (Mycota), a 5,6\% - грибоподобными организмами (Chromista). Среди зарегистрированных истинных грибов больше видов, относящихся к сумчатым грибам (Ascomycota), так к ним относятся 14 из 17 видов истинных грибов, или $82,4 \%$. Остальные 17,6\%, т.е. 3 вида (Puccinia sorghi, Sorosporium reilianum u Ustilago zeae), относятся к базидиомицетным грибам (Bazidiomycota). Cpeди аскомицетных грибов встречаются как анаморфы (Alternaria alternata, Botrytis cinerea, Colletotrichum graminicola, Diplodia zeae, Fusarium graminearum, F.oxysporum, F.verticillioides, Nigrospora oryzae и Septoria maydis), так и телеморфы (Gibberella zeae, Helminthosporium maydis, H.turcicum, Sclerotinia libertiana и Scl.sclerotiorum).

Следует отметить, что в формировании микобиоты растения кукурузы также активно участвуют телеморфы, что отличает кукурузу от многих других растений. Так, в исследованиях, проводимых в Азербайджане, обнаружено, что в формировании микобиоты того или иного растения, а также биотопа, большее участие принимают анаморфы грибов, чем их телеоморфы. В кукурузе эти телеморфы составляют одну треть от общей аскомикобиоты. Для сравнения можно отметить, ч то удельный вес телеморфов в формировании микобиоты томатов составляет всего 10\%, то есть 1/10. 
Таблица 2. Обнаруженные болезни и частота встречаемость их возбудителей

\begin{tabular}{|l|l|l|l|}
\multirow{2}{*}{ № } & \multirow{2}{*}{ Наименование болезней } & Возбудителей болезни & $\begin{array}{l}\text { Частота встречаемость } \\
\text { возбудителей болезни } \\
\text { по образцом (\%) }\end{array}$ \\
\hline \multirow{2}{*}{2} & Стеблевые гнили & Glomerella zeae & 50,7 \\
\hline \multirow{2}{*}{3} & \multirow{2}{*}{ Гелминтоспориоз } & H.maydis & 48,4 \\
\cline { 3 - 4 } & \multirow{2}{*}{ Белая гниль или склероспориоз } & H.turcicum & 23,2 \\
\hline 4 & Септориоз & S.sclerotiorum & 51,2 \\
\hline 5 & Алтернариоз & Scl.libertiana & 26,7 \\
\hline 6 & Диплодиоз & Septoria maydis & 53,3 \\
\hline \multirow{2}{*}{7} & & A.alternata & 31,2 \\
\hline 8 & Фузариоз & Diplodia zeae, & 7,5 \\
\hline 9 & Антракноз & Fusarium graminearum & 5,2 \\
\cline { 3 - 4 } & Серая гниль & F.oxysporum & 28,9 \\
\cline { 3 - 4 } & F.verticillioides & 6,9 \\
\hline 10 & Нигроспориоз & G.graminicola & 20,6 \\
\hline 11 & Ржавчина & B.cinerea & 8,7 \\
\hline 12 & Полегание сеянцев & Nigrospora oryzae & 9,1 \\
\hline 13 & Пыльная и пузурчатая гоолвнья & P.sorghi & 3,2 \\
\hline
\end{tabular}

Таблица 3. Характеристика частоты встречаемости видов, участвующих в формировании патогенной микобиоты кукурузы

\begin{tabular}{|c|c|c|c|}
\hline & Доминантные & Часто встречающиеся & $\begin{array}{l}\text { Случайные и редкие } \\
\text { виды }\end{array}$ \\
\hline Виды грибов & $\begin{array}{l}\text { G.zeae } \\
\text { H.maydis S.sclerotiorum, } \\
\text { S.maydis }\end{array}$ & $\begin{array}{l}\text { A.alternata, F.oxysporumG.graminicolaH.turcicum, Scl. } \\
\text { libertiana }\end{array}$ & $\begin{array}{l}\text { Diplodiazeae, } \\
\text { Fusarium graminearum } \\
\text { F.verticillioides } \\
\text { B.cinerea } \\
\text { Nigrosporaoryzae } \\
\text { Puccinia sorghi } \\
\text { Pythium debaryanum } \\
\text { Sorosporium reilianum, } \\
\text { U.zeae }\end{array}$ \\
\hline $\begin{array}{l}\text { Диапазон } \\
\text { изменения частоты } \\
\text { встречаемости (\%) }\end{array}$ & $48,4-53,3$ & $20,6-31,2$ & $3,5-9,1$ \\
\hline
\end{tabular}

Следует также отметить результаты по видовому составу микобиоты кукурузы, что связано с эпифитностью и патогенностью грибов, участвующих в формировании микобиоты того или иного растения. Так, при характеристике той или иной микобиоты учитывается также и то, что вызывают ли грибы заболевание или нет. Возбудители заболеваний участвуют в образовании патогенной микобиоты, а не вызывающие заболевания - эпифитной микобиоты. Все грибы, зарегистрированные в образцах, взятых с кукурузы, были подтверждены исследованиями как возбудители того или иного заболевания. Среди зарегистрированных грибов не обнаружены грибы, характеризуемые как эпифиты. Однако это не означает, что не существует эпифитной микобиоты, присущей для кукурузы. Пробы отбирались только с пораженных участков растения, поэтому в исследовании не учитывались грибы, участвующие в формировании её эпифитной микобиоты. Однако, в процессе обработки образцов выявлялись некоторые непатогенные грибы (например, Trichoderma harzianum, Chaetomium sp. и др.), но так как в качестве объекта исследования были выбраны грибы, вызывающие заболевания кукурузы, было сочтено целесообразным не учитывать непатогенные виды, а обнаруженные грибы приняты как виды, участвующие в формировании патогенной микобиоты кукурузы. Другими словами, данный этап исследования, показал, что в формировании патогенной микобиоты 
кукурузы участвуют 18 видов грибов, и все они характеризуются как фитопатогены.

На следующем этапе исследования были охарактеризованы грибы - возбудители заболеваний кукурузы и степень распространения заболевания, а также частота встречаемости возбудителей. Полученные результаты показали, что зарегистрированные грибы характеризуются разными показателями как по характеру вызываемых ими заболеваний, так и по частоте встречаемости в образцах, взятых с кукурузы (табл. 2).

Как видно, зарегистрированные в исследовании 18 видов грибов вызывают 13 заболеваний кукурузы, а самая высокой частотой встречаемости в условиях проведенного исследования обладал гриб Septoria maydis- возбудитель септориоза. В целом следует отметить, что грибы согласно принятой системе оценок для характеристики распространения в той или иной экосистеме, а также в конкретном ценозе и растении, делятся на 3 группы - первая группа является доминирующей (ЧВ $\leq 50,0 \%)$, Вторая группа - часто встречающиеся $(10,0 \% \leq 4 B \leq 40 \%)$, третья - случайные и редкие виды (ЧВ $\leq 10 \%)$. Характеристика грибов, участвующих в образовании патогенной микобиоты кукурузы в данном аспекте показала, что только 4 вида, способных вызывать заболевание кукурузы, обладают частотой встречаемости, присущей доминирующим видам (табл. 3). К часто встречающимся относятся 5 видов, а к редким - 9 видов грибов.

Оценивая регистрируемые заболевания и частоту встречаемости грибов, участвующих в их образовании, в фитопатологическом аспекте становится очевидным, что растение кукурузы, выращиваемое в Азербайджане, в первую очередь в Ленкоранско-Астаринском экономическом районе, является не очень благоприятным с фитопатологической точки зрения. Учитывая относительно высокое количественное значение ЧВ, характерное для грибов, вызывающих опасные заболевания, такие белая и корневая гниль, гельминтоспориоз, септориоз и фузариоз, нет сомнений в том, что следует принимать профилактические меры для ограничения этих заболеваний, особенно активности их возбудителей.

\section{ЛИТЕРАТУРА}

1. Атлас экономически значимых растений и вредных объектов России и сопредельных государств. // http://www.agroatlas.ru/diseases

2. Билай В.И. Определитель токсинобразующих микромицетов./ В.И. Билай, 3.А. Курбацкая. -Киев: Наукова думка, — 1990.—236с.

3. Волгин В.И., Романенко Л.В., Прохоренко П.Н., Федорова 3.Л., Корочкина Е.А. Полноценное кормление молочного скота - основа реализации генетического потенциала продуктивности — М.: РАН, 2018. - 260 с.

4. Гулидова В.А., Хрюкина Е.И., Сергеев Г.Я. Кукуруза на зерно. -Воронеж: МТС Агроальянс, —2017. — 51 с.

5. Методы экспериментальной микологии /под ред. Билай В.И. - Киев: - Наукова думка, - 1982, — 500с.

6. Нетрусов А.И., Практикум по микробиологии./ А.И. Нетрусов, М.А. Егорова, Л.М. Захарчук -М.: Издательский центр «Академия»,- 2005,-608с.

7. Саттон Д., Фотергилл А., Риналди М. Определитель патогенных и условно патогенных грибов. — Москва: Мир, — 2001, — 486c.

8. Х Хохряков М.К. Определитель болезней растений. /М.К. Хохряков, К.М. Доброзракова, М.Ф. Степанова, — Санкт Петербург: Наука, 一2003,-535с.

9. Drenth A. and Guest, D.I. Fungal and Oomycete Diseases of Tropical Tree Fruit Crops//Annual Review of Phytopathology, - 2016, -v.54, № 1, -p.373-395

10. FA0. 2017. The future of food and agriculture — Trends and challenges. Rome. http://www.fa0.org/3/i6583e/i6583e.pdf

11. https://www.stat.gov.az

12. Kirk P.M., Stalpers J.A. Dictionary of the fungi, 10th edn. CABI publishing. - Wallingford (UK), 2008, $600 \mathrm{p}$.

13. Klich M.A. Identification of common Aspergillus species. Baarn: CBS. - 2002. - 116 p.

14. Muradov P.Z., Shirinova G.F., Asgerli L.X., Allahverdiyev E.I., Gasımov C.F. Specıes compositıon of fungı causıng dıseases in agrıcultural plants in agrarıan sector of Azerbaijan.//Journal of Applied and Natural Science, - 2019, -v.11(4), -p.785-790

15. Savary S. et al. The global burden of pathogens and pests on major food crops.// Nature Ecology \& Evolution, - 2019, -v.3, -p.430-439.

(С Гасумов Джейхун Фаиг оглы ( ceyhun_qasimov_75@mail.ru ).

Журнал «Современная наука: актуальные проблемы теории и практики» 